Annals of Warsaw University of Life Sciences - SGGW

Land Reclamation No 45 (1), 2013: 61-70

(Ann. Warsaw Univ. of Life Sci. - SGGW, Land Reclam. 45 (1), 2013)

\title{
The stabilization and protection of shorelines using the broadleaf cattail and reed sweet grass
}

\author{
WERONIKA KOWALIK, KINGA PACHUTA, JERZY JEZNACH \\ Department of Environmental Sciences, Warsaw University of Life Sciences - SGGW
}

\begin{abstract}
The stabilization and protection of shorelines using the broadleaf cattail and reed sweet grass. The article presents the results of studies on the mechanical properties of the broadleaf cattail Typha latifolia and reed sweet grass Glyceria maxima. The necessary study samples were collected from Lake Urszulewskie near Sierpc, Poland. The experiment was conducted using an Instron 5966 universal tensile strength testing machine. Tensile forces and the tensile strength of the individual parts of both plant species, i.e. below-ground stems (rhizomes), base of the stem and above-ground stems, were determined and compared with each other. The STATISTICA program was used for analysis. The calculated tensile strength values were compared to data of selected tree, shrub and plant species provided by other authors.
\end{abstract}

Key words: tensile forces, tensile strength, helophytes

\section{INTRODUCTION}

The stabilization and protection of shorelines using helophytes, that is swamp plants, plays an important role in ecological engineering activities. The broadleaf cattail Typha latifolia and reed sweet grass Glyceria maxima are such type of plants. They naturally protect the bottoms of water bodies and shorelines against erosion, thanks to traits such as: the ability to grow in water (up to $50 \mathrm{~cm}$ in depth) and wetland areas with periodically changing humidity, a resistance to human pressure, the ease at which they propagate vegetatively by means of modified stems, that is rhizomes or stolons, as well as relatively high tensile strength. Reed sweet grass and cattail stems can grow as much as a few dozen centimeters per year, which facilitates the expansion of their colonies. Moreover, the number of stems and tensile strength of individual plant components play an important role when it comes to environmental engineering and hydrotechnical construction. On the whole, the higher the density of communities, the more stable and resistant they are to changeable environmental conditions. However, this depends on the plant species and the mechanical strength of its above- and below-ground plant parts (Schiechtl 1999). The present article compares and describes selected mechanical properties of the broadleaf cattail and reed sweet grass.

\section{MATERIAL AND METHODS}

The tensile strength of above-ground stems and rhizomes of the broadleaf cattail Typha latifolia and reed sweet grass Glyceria maxima, as well as those parts of the stem which are especially prone to tearing, i.e. the bases of stems where they turn into rhizomes, were determined. 
Samples of reed sweet grass were collected from Lake Urszulewskie near Sierpc, Poland, from fully-developed, fully-established communities. Whole plant samples were collected by hand. Selection took place on spot, eliminating specimens which showed signs of mechanical damage, deformation or disease. The selected samples, with relatively similar diameters of the above-ground stems and rhizomes, were transported to laboratories of the Water Center of the Warsaw University of Life Sciences. In order to secure them from water loss, the plants were transported in thick plastic bags. Tensile strength experiments were conducted the same day. When this proved to be impossible, the bagged plant samples were placed in basins at the Water Center and stored for no longer than three days. The experiment lasted from the middle of June to the beginning of September. A total of approximately 50 samples of the broadleaf cattail and 60 samples of reed sweet grass were delivered to the laboratory.

a

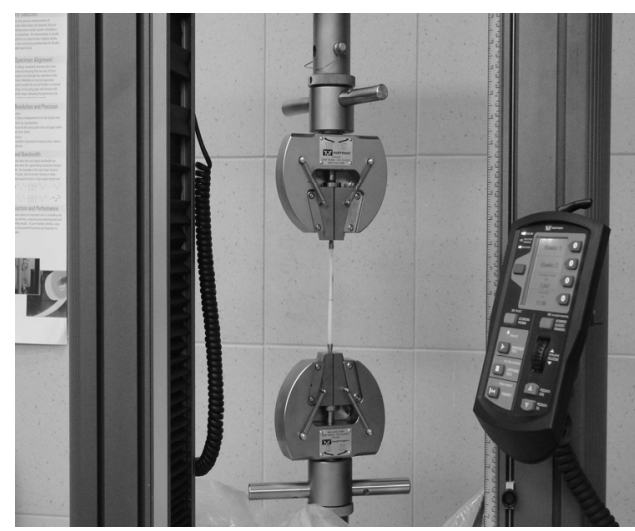

The tensile strength of individual plants parts was determined using an Instron 5966 universal tensile strength testing machine (Instron 2009a), with a measuring range of strength values of up to $10 \mathrm{kN}$. The analysis was registered using the Bluehill 2 program (Instron $2009 b$ ). Figure 1 presents the types of jaw clamp modifications used for samples less than $16 \mathrm{~mm}$ in diameter (1a) and over $16 \mathrm{~mm}$ in diameter (1b), respectively. For purposes of static tensile strength tests conducted on the base of the stem, the bottom clamp was modified (Fig. 2a and b).

Seven valid, static tensile strength tests were conducted on the broadleaf cattail stem, with 12 successful trials carried out on the base of the stem. Ten trials on the below-ground stems (rhizomes) were deemed valid. In the case of reed sweet grass, 13, 23 and 26 tests respectively on the individual plant elements were considered to be valid.

The range of cross-section diameters of the individual parts of the broadleaf

b

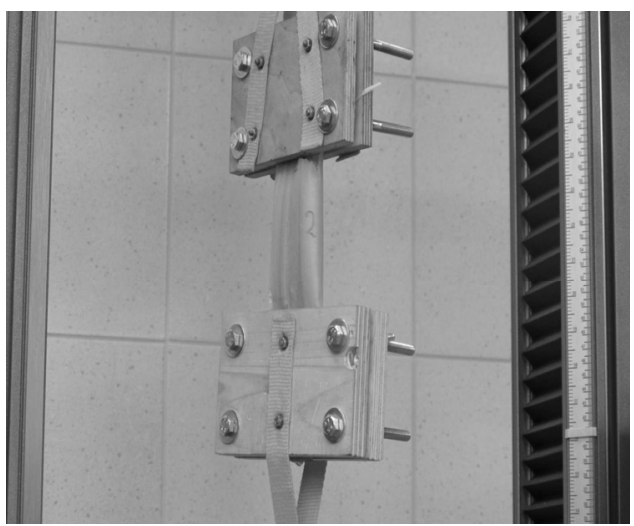

FIGURE 1. Photographs illustrating the types of clamps on an Instron 5966 universal tensile strength testing machine used for measuring the tensile strength of above-ground stems $<16 \mathrm{~mm}$ (a) and $>16 \mathrm{~mm}$ (b) in diameter 
a

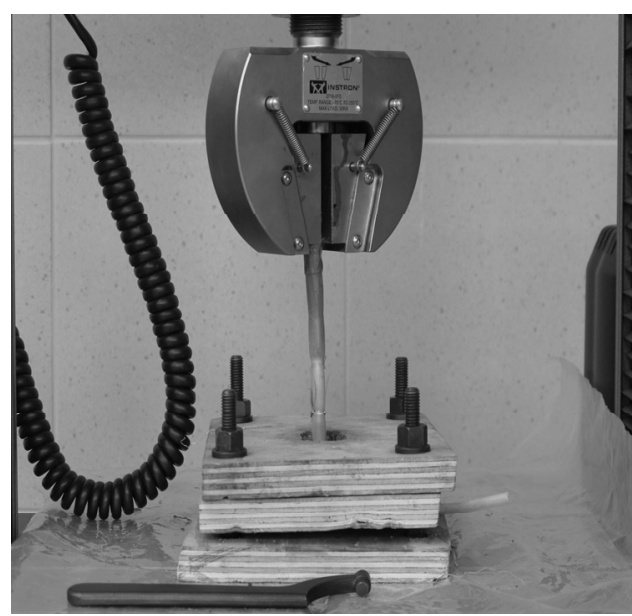

$\mathrm{b}$

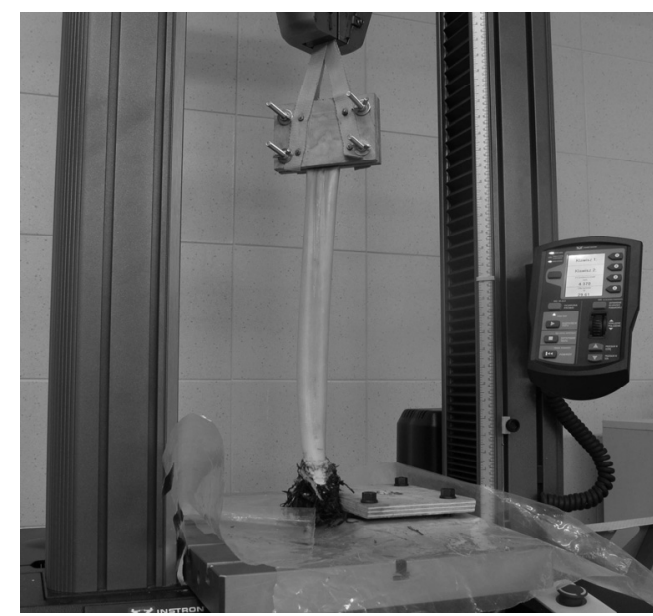

FIGURE 2. Photographs illustrating the types of clamps on an Instron 5966 universal tensile strength testing machine used for measuring the tensile strength of the base of the stem $<16 \mathrm{~mm}$ (a) and $>16 \mathrm{~mm}(\mathrm{~b})$ in diameter

TABLE 1. Range of cross-section diameters of individual broadleaf cattail and reed sweet grass parts

\begin{tabular}{|l|c|c|}
\hline \multirow{2}{*}{ Analyzed plant parts } & Broadleaf cattail & Reed sweet grass \\
\cline { 2 - 3 } & \multicolumn{2}{|c|}{$\mathrm{mm}^{2}$} \\
\hline Above-ground stem & $600-1,500$ & $19-117$ \\
\hline Base of stem & $363-904$ & $16-110$ \\
\hline Rhizome & $176-230$ & $9-53$ \\
\hline
\end{tabular}

attail and reed sweet grass used for tensile strength tests has been presented in Table 1.

The results were calculated statistically using STATISTICA computer software. In order to precisely determine the significance of differences between the average values, the ANOVA - analysis of variance LSD test was applied at a significance level of 0.05 , and so significant for $\mathrm{p}<0.050$. Standard deviation was presented for the average values in the form of error bars.

\section{RESULTS AND DISCUSSION}

The above-ground stem was characterized by the highest tensile force values of the three analyzed parts of the broadleaf cattail $(551.4 \mathrm{~N})$. Next, was the base of the stem with an average tensile force of $408.3 \mathrm{~N}$, and lastly the rhizome $-180.9 \mathrm{~N}$ (Fig. 3).

Similarly, in the case of reed sweet grass the average tensile forces were also the highest for the above-ground stem $(93.5 \mathrm{~N})$, slightly lower for the base of the stem $(90.8 \mathrm{~N})$, and the lowest in the case of the rhizome (49.6 N) (Fig. 3). 


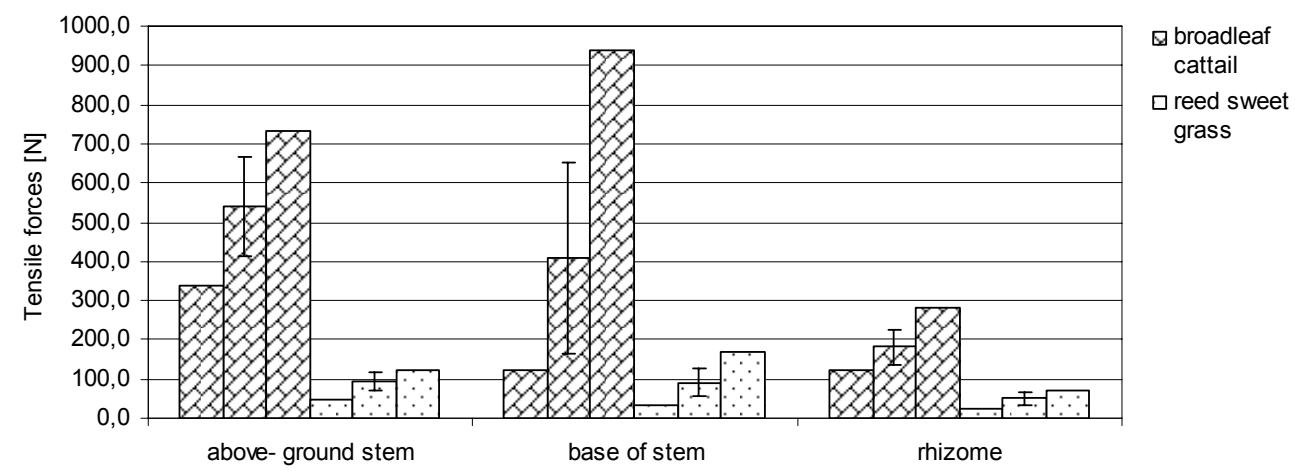

FIGURE 3. Minimum, average and maximum tensile forces and standard deviation for the individual broadleaf cattail and reed sweet grass parts

When looking at the minimum tensile forces of broadleaf cattail parts, their values were found to be the highest for the above-ground stem $(338.0 \mathrm{~N})$ and similar for the base of the stem and the rhizome (121.3 and $123.9 \mathrm{~N}$ respectively) (Fig. 3).

In reed sweet grass the minimum tensile forces were also found to be the highest for the above-ground stem $(47.2 \mathrm{~N})$. The base of the stem and rhizome were characterized by respective values of 34.0 and $23.6 \mathrm{~N}$ (Fig. 3).

The values of maximum tensile forces for the broadleaf cattail were the highest for the base of the stem $(939.6 \mathrm{~N})$, next the above-ground stem $(734.3 \mathrm{~N})$, and lastly, the rhizome (282.3 N) (Fig. 3).

The values of maximum tensile forces in the analyzed reed sweet grass were characterized by the same order - the highest for the base of the stem $(166.8 \mathrm{~N})$, then the above-ground stem $(123.9 \mathrm{~N})$ and finally, the rhizome (70.3 N) (Fig. 3).

The significance of differences between the average tensile forces recorded for the individual parts of reed sweet grass and the broadleaf cattail has been presented in Table 2.

The highest value of average tensile strength for the broadleaf cattail was observed in the rhizome $(748.8 \mathrm{kPa})$.

TABLE 2. Significance of differences between average tensile forces for individual parts of reed sweet grass and the broadleaf cattail.

\begin{tabular}{|l|l|c|c|c|c|c|c|}
\hline \multirow{2}{*}{ Plant species } & \multirow{2}{*}{ Plant parts } & \multicolumn{7}{|c|}{$\mathrm{p}$ value } \\
\cline { 3 - 8 } & & $(1)$ & $(2)$ & $(3)$ & $(4)$ & $(5)$ & $(6)$ \\
\hline \multirow{3}{*}{$\begin{array}{l}\text { Reed sweet } \\
\text { grass }\end{array}$} & above-ground stem (1) & $\times$ & 1.0000 & 0.8687 & 0.0001 & 0.0001 & 0.3578 \\
\cline { 2 - 8 } & base of stem (2) & 1.0000 & $\times$ & 0.8352 & 0.0001 & 0.0001 & 0.2221 \\
\cline { 2 - 8 } & rhizome (3) & 0.8687 & 0.8352 & $\times$ & 0.0001 & 0.0001 & 0.0298 \\
\hline \multirow{3}{*}{$\begin{array}{l}\text { Broadleaf } \\
\text { cattail }\end{array}$} & above-ground stem (4) & 0.0001 & 0.0001 & 0.0001 & $\times$ & 0.0974 & 0.0001 \\
\cline { 2 - 8 } & base of stem (5) & 0.0001 & 0.0001 & 0.0001 & 0.0974 & $\times$ & 0.0001 \\
\cline { 2 - 8 } & rhizome (6) & 0.3578 & 0.2221 & 0.0298 & 0.0001 & 0.0001 & $\times$ \\
\hline
\end{tabular}


Next in line was the base of the stem with an average tensile strength of 737.3 $\mathrm{kPa}$, and lastly the above-ground stem (551.4 kPa) (Fig. 4).

In the case of reed sweet grass, the average tensile strength was highest for the rhizome $(2,725.7 \mathrm{kPa})$, next the above-ground stem $(1,954.4 \mathrm{kPa})$ and finally, the base of the stem (1,369.9 kPa) (Fig. 4).

When analyzing the minimum tensile strength in selected parts of the broadleaf cattail, the highest values were recorded for the rhizome $(701.5 \mathrm{kPa})$, with the above-ground stem and base of the stem characterized by similar values $(326.4$ and $316.5 \mathrm{kPa}$ respectively) (Fig. 4).

In reed sweet grass minimum tensile strength was shown to be the highest for the rhizome $(1,195.5 \mathrm{kPa})$, then the above- -ground stem $(887.7 \mathrm{kPa})$ and finally, the base of the stem (534.7 kPa) (Fig. 4).

Maximum tensile strength values for selected parts of the broadleaf cattail were the highest for the base of the stem $(1,918.2 \mathrm{kPa})$, then the above-ground stem $(1,203.9 \mathrm{kPa})$ and lastly, the rhizome (815.5 kPa) (Fig. 4).

Where reed sweet grass is concerned, maximum tensile strength was the highest for the rhizome $(4,566.3 \mathrm{kPa})$, followed by the above-ground stem $(4,195.2 \mathrm{kPa})$, and the lowest in the base of the stem $(2,648.6 \mathrm{kPa})$ (Fig. 4).

The significance of differences between the average tensile strengths of the individual parts of reed sweet grass and the broadleaf cattail has been presented in Table 3.

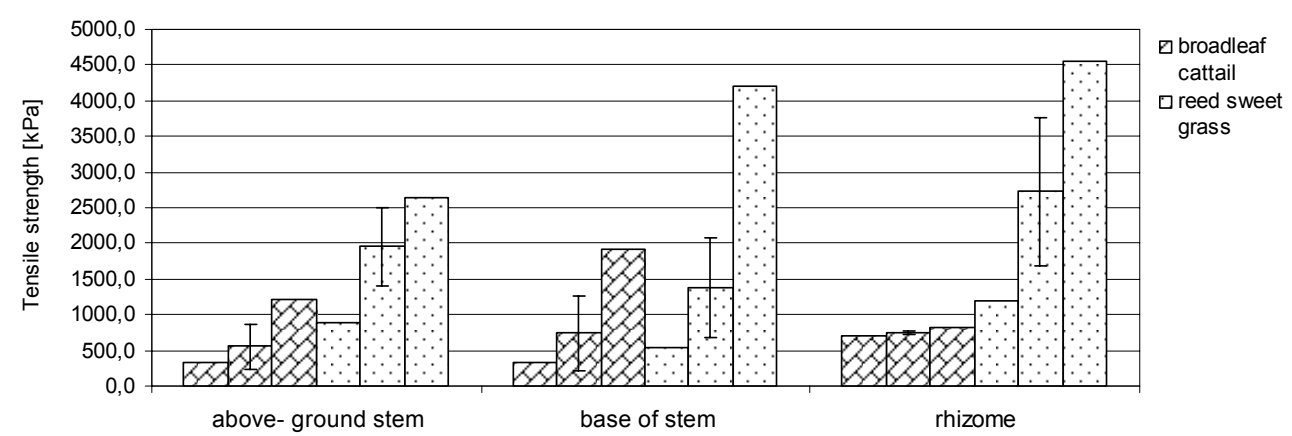

FIGURE 4. Minimum, average and maximum tensile strength and standard deviation for individual parts of the broadleaf cattail and reed sweet grass

TABLE 3. Significance of differences between average tensile strengths for individual parts of reed sweet grass and the broadleaf cattail

\begin{tabular}{|l|l|c|c|c|c|c|c|}
\hline \multirow{2}{*}{ Plant species } & \multirow{2}{*}{ Plant parts } & \multicolumn{7}{|c|}{$\mathrm{p}$ value } \\
\cline { 3 - 8 } & & $(1)$ & $(2)$ & $(3)$ & $(4)$ & $(5)$ & $(6)$ \\
\hline \multirow{3}{*}{ Reed sweet grass } & above-ground stem (1) & $\times$ & 0.2462 & 0.0515 & 0.0029 & 0.0005 & 0.0021 \\
\cline { 2 - 9 } & base of stem (2) & 0.2462 & $\times$ & 0.0001 & 0.2198 & 0.2087 & 0.3205 \\
\cline { 2 - 8 } & rhizome (3) & 0.0515 & 0.0001 & $\times$ & 0.0001 & 0.0001 & 0.0001 \\
\hline \multirow{3}{*}{ Broadleaf cattail } & above-ground stem (4) & 0.0029 & 0.2198 & 0.0001 & $\times$ & 0.9954 & 0.9939 \\
\cline { 2 - 8 } & base of stem (5) & 0.0005 & 0.2087 & 0.0001 & 0.9954 & $\times$ & 1.0000 \\
\cline { 2 - 8 } & rhizome (6) & 0.0021 & 0.3205 & 0.0001 & 0.9939 & 1.0000 & $\times$ \\
\hline
\end{tabular}


Figure 5 presents graphs which are typical for tensile forces tests of individual reed sweet grass parts. In the graph prepared for the base of the stem, tensile forces can be observed to increase linearly along with displacement. Upon reaching the maximum value, signifying that the sample had been destroyed, a sharp decline of tensile forces is noted, at which time the displacement remains unchanged. Next, the line levels out becoming nearly parallel to the $\mathrm{x}$-axis and is characterized by multiple irregularities; this signifies that when the sample is torn in the area where the above-ground stem turns into the rhizome, numerous adventitious roots and dead plant remains create resistance. When all elements are destroyed, tensile force drops abruptly without changes in its displacement.

In the case of charts prepared for the above-ground stem and rhizome, tensile forces increase correspondingly with displacement (the line takes on a linear form or various degrees of convexity). Upon reaching the maximum value, signifying that the sample had been destroyed, a sharp decline of tensile forces takes place, at which time the displace- ment remains unchanged (the lines takes on a vertical direction). Sometimes slight irregularities (local decreases in tensile forces) appear on the chart, indicating the initial tearing of fibers which precedes the ultimate destruction of the sample.

Figure 6 presents charts which are characteristic of static tensile forces tests on the individual parts of the broadleaf cattail. As can be seen in the line depicting values for the above-ground stem, tensile forces increase linearly with displacement. Upon reaching the maximum value, a gradual, irregular drop is observed up until the moment that stabilization at an almost exact level is achieved. In the chart for the base of the stem, clear breaking points are not evident. Tensile forces increase with displacement. The rhizome curve is characterized by a different appearance. Tensile forces increase with displacement and decline sharply upon having achieved the maximum value. Moreover, in some segments of the charts, numerous irregularities can be observed prior to reaching maximum tensile force values. This indicates that the tearing process is

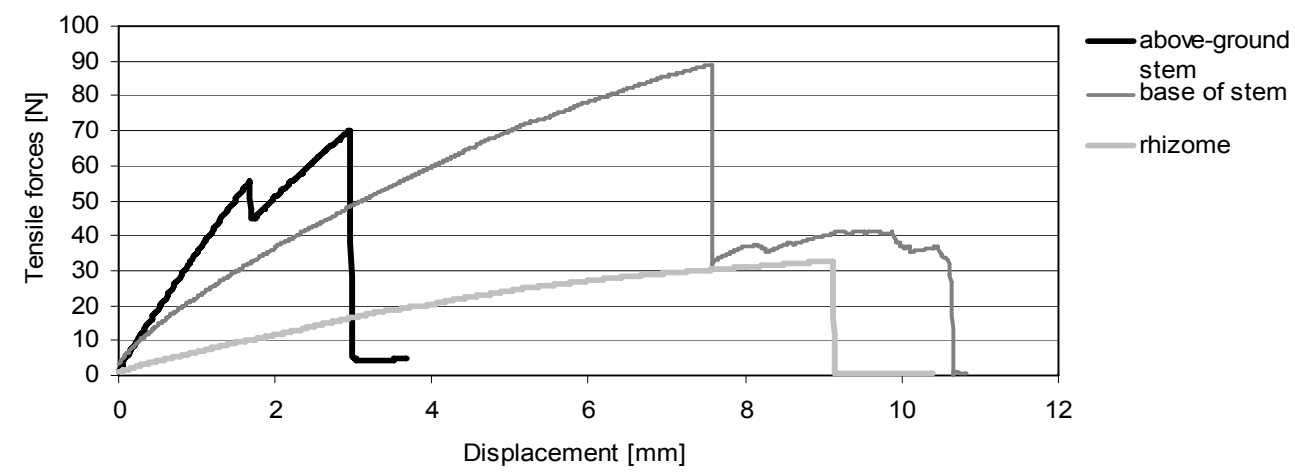

FIGURE 5. The characteristics of subjecting individual parts of reed sweet grass Glyceria maxima to tensile forces 


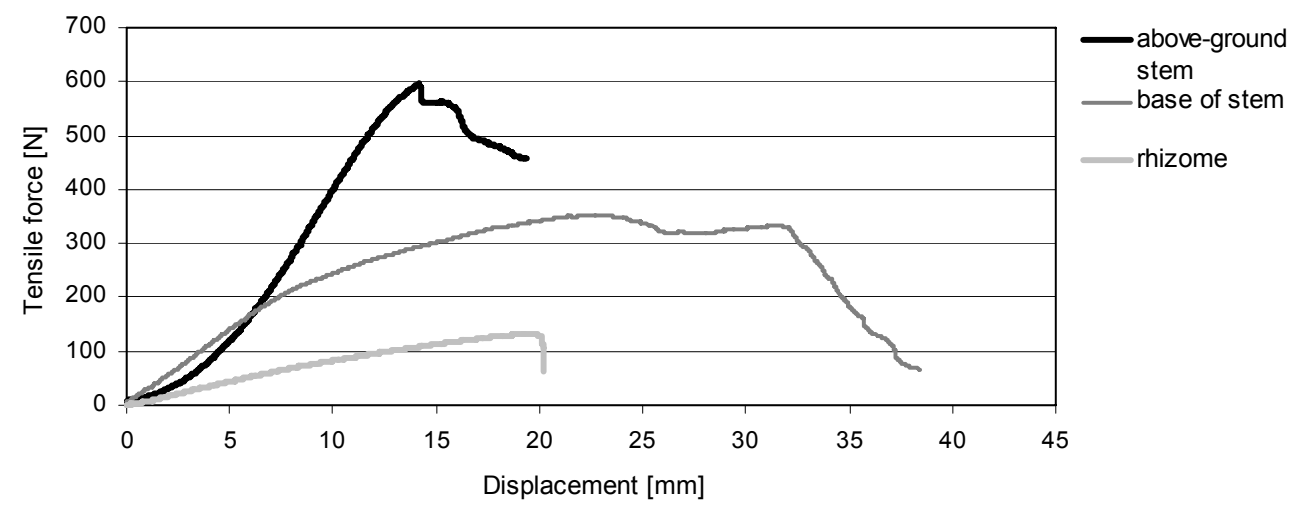

FIGURE 6. The characteristics of subjecting individual parts of the broadleaf cattail Typha latifolia to tensile forces

initiated in places which go unseen by the researcher before reaching the maximum value of tensile forces. This is also the time when numerous cracks appeared in the analyzed samples, often simultaneously in different places.

Average tensile force values for individual parts of the broadleaf cattail are higher than the values of average tensile forces for their respective parts of reed sweet grass. Average tensile forces in the first plant species are 5.8, 4.5 and 3.6 times higher for the above-ground stem, stem base, and rhizome respectively when compared to the respective values of reed sweet grass parts. This occurs because the values of tensile strength increase along with an increase in the cross-sectional area of the stretched sample. On one hand, the inside of the individual cattail parts is filled with tissue and so characterized by larger dimensions. On the other hand, all parts of reed sweet grass have empty internodes, and so the dimensions of their cross-sectional areas are smaller (Table 1).

The opposite situation is observed in the case of average tensile strength values, where higher values for all analyzed plant parts were noted for reed sweet grass. Average tensile strength is 3.5, 1.9 and 3.6 times higher for the aboveground stem, stem base, and rhizome respectively, as compared to respective parts of the broadleaf cattail. The smaller the area of the cross-sectional area of the strained sample, the higher the tensile strength, which stems from the following formula:

$\sigma=\frac{F}{A}$

where:

$F$ - tensile force $[\mathrm{N}]$,

$A$ - cross-sectional area of strained sample $\left[\mathrm{m}^{2}\right]$.

The study results revealed the rhizomes to be the strongest parts of the broadleaf cattail as well as reed sweet grass, with average values of 748.8 and $2,725 \mathrm{kPa}$ respectively.

The obtained average results for the below-ground stem (rhizome) of the broadleaf cattail and reed sweet grass were compared to data from selected tree and shrub species presented by various authors. According to Bischetti et al. 
(2005), the average tensile strength of common beech Fagus silvatica roots was $57,470 \mathrm{kPa}$, and $67,870 \mathrm{kPa}$ for those of the common hazel Corylus avellana. Another author, Rokita (1970), established the average tensile strength of the german tamarisk Myricaria germanica roots as $6,174 \mathrm{kPa}$.

Based on the above findings, it could be mistakenly assumed that the broadleaf cattail and reed sweet grass have worse reinforcing properties than the above-cited species. This is not, however, the case. Both the broadleaf cattail and reed sweet grass form dense communities, where their rhizomes interlace with one another forming systems (areas, layers) which reinforce the soil structure. Countrary to that, trees and shrubs grow separately, retaining large distances between other members of the species. What is more, the common beech is a highly demanding species, which does not tolerate moist, swampy soils very well. Its roots avoid growing below groundwater level and extend in a direction opposite to that of the shoreline (Rokita 1970). The common hazel is not characterized by any specific needs besides its intolerance to an overabundance of water in the ground. The roots of the mentioned trees and shrubs are vulnerable to flooding and will rot after a certain time, losing their reinforcing properties.

The rhizomes of reed sweet grass and the broadleaf cattail are on the opposite side of the spectrum, forming a dense network which reaches even a few meters into the ground. They are very well-adapted to stabilizing the soil surface under conditions of constant flooding, oxygen deprivation, eutrophication, environmental pollution and human pressure. Furthermore, these species have been found to grow on various kinds of soil, from mineral to organic (Podbielkowski and Tomaszewicz 1996; Kłosowski and Kłosowski 2007).

The broadleaf cattail creates extensive communities, which reach out into water depths of up to $2 \mathrm{~m}$, often bordering the pelagial zone. Reed sweet grass grows along the shore, in places where the water depth does not exceed $0.5 \mathrm{~m}$, forming smaller, though just as common, communities. Both plant formations are able to effectively clean domestic sewage, which could potentially end up in bodies of water (Kowalik and Obarska-Pempkowiak 1994; Obarska-Pempkowiak et al. 2010). In addition to this, they create an ecotone zone which connects the land with deeper parts of the water body and is inhabited by the largest variety of land and water animal species, as well as being characteristic of bulrush beds, which are home to endangered amphibians, reptiles and birds requiring active protection (on the territory of Poland) (Minister of Environment Decree on the protection of animal species of 12 October, 2011, Journal of Laws of the Republic of Poland of 2011, no 237 item 1419). Bulrush consisting of the analyzed helophytes is capable of selfregeneration, even in the case of severe damage occurring as a result of, for example, drastic changes in the water level. This does not hold true for concrete and reinforced-concrete reinforcements. 


\section{CONCLUSIONS}

1. The tensile strength of bulrush plants is an important property for hydrotechnics and environmental engineering.

2. The rhizome is the strongest parts of reed sweet grass as well as the broadleaf cattail. In the cattail it is followed by the base of the stem and thirdly, the above-ground stem, whereas in the case of reed sweet grass, the above-ground stem and base of the stem, respectively.

3. The average tensile strength of reed sweet grass and the broadleaf cattail is 2,725 and $748.8 \mathrm{kPa}$ respectively.

4. The broadleaf cattail and reed sweet grass are suitable for protecting the shores of water bodies under conditions which are not well tolerated by many plant species.

\section{REFERENCES}

BISCHETTI G.B., CHIARADIA E., SIMONATO T., SPEZIALI B. 2005: Root strength and root area ratio of forest species in Lombardy (Northern Italy). Plant and Soil 278, 11-22.

KŁOSOWSKI G., KŁOSOWSKI S. 2007: Rośliny wodne $i$ bagienne [Aquatic and swamp plants]. MULTICO, Warszawa [Engl. summ.].

KOWALIK P., OBARSKA-PEMPKOWIAK H. 1994: Zasady pracy małych hydrobotanicznych oczyszczalni ścieków [The functioning of small hydrobotanical water treatment plants]. Mat. Inf. IMUZ, j. 28 [Engl. summ.].

Minister of Environment Decree on the protection of animal species of 12 October, 2011 - Annex 1 (Journal of Laws of the Republic of Poland of 2011, no 237 item 1419).
OBARSKA-PEMPKOWIAK H., GAJEWSKA M., WOJCIECHOWSKA E. 2010: Hydrofitowe oczyszczanie wód i ścieków [Hydrophytic treatment of water and sewage]. PWN, Warszawa.

PODBIELKOWSKIZ., TOMASZEWICZH. 1996: Zarys hydrobotaniki [An outline of hydrobotanics]. PWN, Warszawa [Engl. summ.].

ROKITA Z. 1970: Systemy korzeniowe niektórych drzew i krzewów i ich przydatność do obudowy biologicznej potoków górskich [Root systems of selected trees and shrubs and their suitability for the biological encasement of mountain streams]. Ochrona Środowiska 35, 100-155 [Engl. summ.].

SCHIECHTL H.M. 1999: Inżynieria ekologiczna $w$ budownictwie wodnym i ziemnym [Ecological engineering in hydraulic and land construction]. Arkady, Warszawa [Engl. summ.].

Instron 2009a: 5960 Series Dual Column Frames System Support. Tools Works Inc., Illinois.

Instron 2009b: Bluehill 2 Test Method Development Training Manual. Tools Works Inc., Illinois.

Streszczenie: Stabilizacja i ochrona brzegów wód przy wykorzystaniu pałki szerokolistnej $i$ manny mielec. W artykule przedstawiono wyniki badań nad właściwościami mechanicznymi pałki szerokolistnej Typha latifolia i manny mielec Glyceria maxima. Potrzebne do badań próbki pobrano z Jeziora Urszulewskiego koło Sierpca. Doświadczenia przeprowadzono za pomocą uniwersalnej maszyny wytrzymałościowej Instron 5966. Ustalono siłę zrywającą i wytrzymałość na zerwanie poszczególnych elementów obu gatunków roślin - pędów podziemnych (kłączy), nasady pędów nadziemnych oraz pędów nadziemnych, oraz porównano je ze sobą. Do analizy statystycznej użyto programu STATISTICA. Uzyskane wartości wytrzymałości na rozciąganie porównano z danymi dotyczącymi niektórych gatunków drzew, krzewów i roślin zielnych, podanymi przez innych autorów. 
Słowa kluczowe: siły zrywające, wytrzymałość na rozciaganie, helofity

MS. received 28 June 2013

Author's address:

Katedra Kształtowania Środowiska

Katedra Inżynierii Budowlanej

Wydział Budownictwa i Inżynierii Środowiska

SGGW

ul. Nowoursynowska 159, 02-776 Warszawa

Poland

e-mail: weronika85sier@interia.pl 